\title{
The Role of Religiosity in Work-Life Balance
}

\author{
Salamiah Sari Dewi ${ }^{1}$, Abd. Madjid ${ }^{2}$, Aris Fauzan ${ }^{3}$ \\ ${ }^{1 a}$ Study Program of Psychology of Islamic Education Doctoral, Universitas Muhammadiyah Yogyakarta, \\ Indonesia. \\ ${ }^{1 b}$ Faculty of Psychology, Universitas Medan Area, Indonesia \\ ${ }^{2,3}$ Psychology of Islamic Education Program, Universitas Muhammadiyah Yogyakarta, Indonesia. \\ salamiahsaridewi@gmail.com
}

\begin{abstract}
Today's work scenario is characterized by a fast rate of change, intense pressure, constant decline, changing demographics, increasing use of technology have affected the lives of employees. A person working aims to find life-work balance in his personal life. Work-life balance has implications for attitudes, behavior, welfare and organizational effectiveness. Therefore, it is necessary to have an attitude of appreciation from a sense of diversity towards a religion and one's belief in the existence of God which is manifested by obeying His commands and prohibitions with all one's heart and soul which is called religiosity. Religious activities are closely related to religiosity, not only when performing rituals (worship), but also other activities including work. Thus, religiosity can predict a person's behavior at work. This article reviews the literature on the role of religiosity in the work-life balance domain for employees, which emphasizes the importance of work-life balance supported by the values of religiosity of the employees.
\end{abstract}

Keywords employees, religiosity, work-life balance

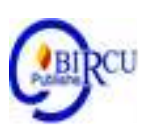

\section{Introduction}

The state of Indonesia is a country that has a state basis regarding the value of religiosity, the value of justice, character and other noble values. The basis of the Indonesian nation state is Pancasila, which contains 5 points of Pancasila, namely Almighty Godliness, Just and Civilized Humanity, Indonesian Unity, Democracy Led by Wisdom in Representative Consultations, and Social Justice for All Indonesians. Pancasila, which is a civic education lesson that is practiced in schools, is one of the tools used as character formation in addition to religious education lessons as a character shaping human religiosity (Arwani, 2013).

Religion teaches about morals to interact with the environment, between humans, humans and other creatures, and humans with their God. So that in any religion the teachings of "morals" are the same, but humans as the object of these religious doctrines have differences in capturing the meanings of these teachings. This means that the sense of diversity (religiosity) of each individual is different, but basically every human being has a sense of religiosity (religiosity). So, it is not wrong if there are still "religious" people who still have "morals" which in the view of other humans are not good and deviate from predetermined rules (Adhim, 2009).

According to Yusuf \& Khan (2015) religious belief is belief in mythological, supernatural, or spiritual realities from a religious aspect. Religious beliefs, which derive from ideas exclusive to religion, relate to the existence, characteristics and worship of God, God's intervention in the universe and human life, or deontological explanations for religious values and practices centered on the teachings of spiritual leaders or group. Religiosity can 
predict a person's behavior at work. A study conducted by Elci (2007) found that religious values have a positive and significant effect on hard work orientation. Several studies have also indicated that religiosity has a positive effect on work attitudes (McClelland. 1961; Simmons. 2005: Weaver \& Agle, 2002) and several studies have found no effect on work attitudes (Chusmir \& Kobera. 1988; Ford \& Richardson, 1994).

The world of work is a world where a group of individuals performs a work activity, in which these activities are contained within a company or organization. According to Robbins (2008) this company or organization is a consciously organized social unit, consisting of 2 or more people who function on a relatively continuous basis to achieve a goal or a series of common goals. The world of work today requires reliable human resources as a form of resilience and the ability of an individual to face changes, one of which is globalization. Work is a person's main goal in achieving self-actualization of one's potential.

On the way to work, most people begin to feel that there are other things to consider besides work. What is meant is the personal life he lives in his daily life. Life at work, work and family, work and personal fulfillment, work and social life all paint problems of a harmonious and balanced arrangement between work and other life. Work-life conflicts will occur when work activities can hinder the fulfillment of employees' other needs. One important factor is the extent to which work-life balance generally prevails throughout the organizational hierarchy. For an employee, daily life is concentrated on two different activities and two different places (Singh, 2013).

On the one hand, employees are part of an organization to devote themselves to and earn a living. Meanwhile, on the other hand, an employee is also part of and responsible for the family he owns. Concentration and time sharing must be done by employees so that both can run in a balanced manner. The division that is done is not a mathematical calculation which must be given the same amount. The job he owns supports his family life. Likewise, family life will support employees in carrying out all their activities. When an individual does not maintain a balance of life and works too much in an organizational setting, this can lead to disturbed psychological (mind, spirit) and concentration behavior, as a result his productivity will also be low, which in turn triggers stress and will disrupt work life balance (work). -life balance) (Singh, 2013).

The definition of work-life balance according to Schermerhorn (2005) is a person's ability to balance the demands of work with personal and family needs. In other words, an employee really needs a good work-life balance in the organization because an employee has very high demands, which must be able to balance the relationship between the work required to go according to the plan the organization wants and the need for family as well as for oneself. yourself, for example taking care of one's own health, paying attention to family development, time for resting, vacationing with family and so on. Suhardono (in Ramadhani, 2013) hopes that what employees do for work and family goes hand in hand in harmony, work is a part of life that will produce totality in work, work, and life. So it's not just a balance (balance).

The definition of work-life balance according to Schermerhorn (2005) is a person's ability to balance the demands of work with personal and family needs. In other words, an employee really needs a good work-life balance in the organization because an employee has very high demands, which must be able to balance the relationship between the work required to go according to the plan the organization wants and the need for family as well as for oneself. yourself, for example taking care of one's own health, paying attention to family development, time for resting, vacationing with family and so on. Suhardono (in Ramadhani, 2013) hopes that what employees do for work and family goes hand in hand in harmony, 
work is a part of life that will produce totality in work, work, and life. So it's not just a balance (balance).

Therefore, this research was conducted to explore theoretically the topics of the role of religiosity in work-life balance for employees in the world of work. The sub-sequential section will explain the theoretical definitions of religiosity and work-life balance and the relationship between these two terms, especially in the world of work. The last section will discuss the serious aspects of religiosity in life.

\section{Review of Literatures}

\subsection{Dimensions and Determining Factors of Religiusity}

Ancok \& Suroso (2001) define religiosity as a form of human relationship with its creator through religious teachings that have been internalized in a person and reflected in their attitudes and behavior. According to Glock \& Stark (in Ancok \& Suroso, 2001) the dimensions of religiosity consist of five types, namely:

1. The dimension of belief is an ideological dimension that provides an overview of the extent to which a person accepts things dogmatically from their religion. In Islam, the dimension of belief concerns the belief in God, angels, messengers, books of Allah, heaven and hell, as well as qadha and qadar.

2. The dimension of worship or religious practice is the dimension of ritual, namely the extent to which a person carries out his ritual obligations, such as prayer, fasting, zakat, haj, reading the Koran, prayer, zikir and others, especially for the people. Islam.

3. The practice or consequence dimension, refers to the degree to which a person's behavior is motivated by the teachings of his religion, namely how individuals relate to their world, especially with other humans. This dimension includes helping behavior, cooperating, giving, upholding justice and truth, being honest, forgiving, not stealing, obeying Islamic norms in sexual behavior, striving for a successful life in Islam, and so on.

4. The dimension of knowledge, refers to how much a person's level of knowledge of the teachings of his religion, especially regarding the main teachings of his religion, as contained in his holy book. In Islam this dimension concerns knowledge of the contents of the Al-Qur'an, the main teachings that must be believed and implemented, Islamic laws, Islamic history, and so on.

5. The dimension of appreciation, refers to the extent to which a person feels and experiences religious feelings and experiences. This dimension is manifested in the feeling of being close to or familiar with God, the feeling of his prayers being answered often, the feeling of serene happiness, feeling of tawakkal, feeling solemn when worshiping, and so on (Ancok \& Soroso, 2001).

The dimensions of religiosity can be well formed to understand aqidah, spirituality, ihsan, knowledge, practice, if the five dimensions become a unity that is interrelated with one another. However, it is different with Lenski (in Krauss, at all, 2005) that the dimensions of individual or group religions consist of four dimensions, namely:

1. The associational dimension, namely the relationship dimension includes the frequency of religious involvement. For example: how often does someone pray and how often they read the Al-Qur'an.

2. The communal dimension, namely the dimension of the relationship with choices and virtues with God. For example: fasting, charity, and others.

3. The dimension of doctrinal orthodoxy, which is the dimension of acceptance of religious knowledge determined by the scriptures. For example: belief in the existence 
of heaven and hell, practicing the pillars of faith and Islam, staying away from all prohibitions that are forbidden.

4. The dimension of devotionalism, which is the dimension of the involvement of a personal relationship with God. For example: night prayers, dhuha, dhikr.

According to Glock \& Starks (in Kibuuka, 2005), the dimensions of religious character consist of five dimensions, namely:

1. Religious belief (the ideological dimension), which describes a person's belief in accepting dogmatic matters in religious teachings. Every religion has rules that are obeyed and believed by every adherent.

2. Religious practice (the ritualistic dimension), which explains the actions of a person in exercising the obligation to worship in accordance with his / her religion, for example in Islam the main thing that must be done is the obligatory prayer 5 times, reading the Al-Qur'an, praying the sunnah and others .

3. Religious feeling (the experiential dimension), which is related to a person's feelings about religion which begins to be felt about the presence of God which is associated with direct experience in the course of life.

4. Religious knowladge (the intellectual dimension), which is related to one's knowledge, scientific understanding, knowledge, and memorization of the teachings that are the basis of one's religion.

5. Religious effect (the consequential dimension), which deals with knowledge, identification of cause and effect, practice of experience, and belief. This is related to the behavior of someone who is motivated by religious teachings in every part of his life.

\subsection{Identification of Religiusity Values on Employees}

Manpower, workers, employees, human potential as the driving force of the organization in realizing its existence or potential which is an asset and functions as nonmaterial capital in a business organization that can be realized into a real potential physically and non-physically in realizing the existence of the organization (Nawawi, 2011). Employees are every person who works by selling their energy (physical and mental) to a company and receiving remuneration in accordance with the agreement (Hasibuan, 2009).

Employees who work in an organization are people who have received formal or nonformal education. Schools as formal institutions in Indonesia oblige their students to receive religious instruction which aims to instill religious values to uphold the values of Pancasila, especially the first precept, namely God Almighty. Then, a person also gets non-formal religious and religiosity education, namely from his / her environment, especially family. This is what ultimately becomes a provision for employees to develop religiosity in the work environment (Arwani, 2013).

According to Siregar (2020) Employees who have skills in emotional intelligence will be able to read other people's feelings and have social skills which means they are able to manage the feelings of others well. Very emotional intelligence important is owned by every employee in an organization that will help employees connect with other employees and share information and to manage conflicts that arise in carrying out tasks in their work.

Even though it has the roots of the same word, in its use the term religiosity has a different meaning from religion or religion. If religion refers to the formal aspects related to rules and obligations, religiosity refers to aspects of religion that have been lived by individuals in their hearts (Mangunwijaya, 1982). Religiosity is often identified with diversity. Religiosity is defined as how far the knowledge is, how strong is the belief, how much is the practice of worship and rules and how deep is the appreciation of the religion one 
adheres to. For a Muslim, religiosity can be seen from the extent of knowledge, belief, implementation and appreciation of Islam (Nashori and Mucharam, 2002).

Hawari (1996) states that religiosity is a religious appreciation and the depth of belief which is expressed by performing daily worship, praying, and reading holy books. Ancok and Suroso (2001) define religiosity as diversity which means covering various sides or dimensions that not only occur when a person performs ritual behavior (worship), but also when doing other activities driven by supernatural forces. The source of the religious soul is a sense of absolute dependence. The existence of fears of threats from the natural environment and human beliefs about all their limitations and weaknesses. This absolute sense of dependence makes humans look for magical powers from their surroundings that can be used as a protective force in their lives with a power that is outside of themselves, namely God (Jalurilmu.blogspot.com). From the above explanation, it can be concluded that it is the depth of one's religious appreciation and belief in the existence of a god which is manifested by obeying orders and staying away from prohibitions with sincerity of heart and with all body and soul.

In human social life, education not only creates a learning process that intends to bring people to become intellectual potential figures through the transfer of knowledge, but a learning process that leads to efforts to form a society that has character, ethics and aesthetics through the transfer of value. Education can guide humans to achieve a better form of life (Zuhairini, 1993).

The values of religiosity are indeed instilled in schools. Diversity or religiosity, according to Islam, is implementing religious teachings or being Muslim as a whole in carrying out economic, social, political or any activity, a Muslim is ordered to do it in order to worship Allah SWT. Relativity or religiosity can be manifested in various aspects of human life. Religious activity does not only occur when someone performs ritual behavior (worship), but also when doing other activities that are driven by supernatural forces. Not only those that are visible and can be seen with the eye, but also activities that are not visible and occur in a person's heart. Therefore, a person's diversity will cover various sides or dimensions (Muhaimin, 2015).

Rachmawati (2017) in her research identified the religious character of employees of PT. Royal Korindah Purbalingga through several activities including 3-S Culture (smile, greetings, greetings), praying on time and in congregation at the mosque, praying dhuha, reciting prayers together, listening to verses of the Koran and religious songs, clean environment culture, Fashion culture (dress neatly, politely and cleanly), and not smoking. This religious activity actually has a positive impact on the company, such as increasing employee motivation to work, thereby increasing employee performance which in turn makes a good contribution to the company's production continuity.

Najiyah (2017) found that the values of religiosity in employees at PT. Takaful Umum Surabaya Branch has an impact on employee job loyalty. The values of religiosity are identified through the actions of employees in establishing dhuha prayers, greeting when meeting, praying on time and reminding each other in kindness to fellow employees. Then, the manifestation of this act of religiosity has a positive impact on the company, namely employee loyalty which includes employees obeying company regulations, not neglecting the work that is their responsibility to the company, willing to cooperate with other employees, a sense of belonging, establishing good interpersonal relationships in the company and love his job.

Furthermore, research conducted by Fauzan and Tyasari (2012) regarding the identification of religious values in Islamic Junior High School teachers, LP Ma'arif, Malang City. Teachers at SMP LP Ma'arif routinely carry out recitation, say greetings when meeting 
students, read prayers before and after teaching and learning activities, pray Duha and discuss religion with fellow teachers. The positive impact on schools is increased Islamic work ethics and increased work motivation.

Finally, research conducted by Prasetyo (2017) on the identification of religious values in the employees of BPRS PNM Binama. This Sharia Banking employee regularly holds recitation every Friday, greets customers who come, prays on time and considers work to be worship. The positive effect is increased employee performance.

\section{Discussion}

\subsection{Understanding about Work-Life Balance}

This life must be balanced in order for humans to feel the real life in the world. This balance is related to work and life. Humans are often obsessed with a material obtained from work so that they ignore life and social things. Guess (2002) defines Work-Life Balance (WLB) as the ability to provide sufficient time to fulfill commitments, both at work and at home. According to Greenhaus, Collins, and Shaw (2006), balance is generally seen as the absence of conflict. But when linked and included in the definition of work-life balance, balance here comes from effectiveness (good functioning, productive, successful) and positive impacts (satisfying, happy) both for work or family roles.

According to Schermerhorn (in Anggraeni, 2018), work-life balance is a condition of how a person is able to balance the demands of work with personal and family needs. According to Fisher (in Ula et al, 2015) work-life balance is an effort made by individuals to balance two or more roles that are undertaken. When defined as a whole, work-life balance is the extent to which individuals can balance and are equally satisfied in terms of time and psychological involvement with their roles in work life and personal life (for example with spouses, parents, family, friends and community members. ) and there is no conflict between the two roles.

According to Fisher (in Ula et al, 2015) work-life balance is a work stressor which includes four important components, namely:

1. Time, including the amount of time used for work compared to the time used for other activities outside of work.

2. Behavior, which includes actions to achieve the desired goals. It is based on a person's belief that he is able to achieve what he wants in his work and personal goals.

3. Tension, including anxiety, pressure, loss of important personal activities and difficulty maintaining attention.

4. Energy, includes energy used to achieve the expected goals. Energy is a limited source in humans so that if individuals lack energy to carry out activities, it can increase stress. Fisher, Bulger, and Smith (2009) also say that work-life balance has 4 forming dimensions, namely:

1. WIPL (Work Interference with Personal Life), which refers to the extent to which work can interfere with an individual's personal life. For example, work can make it difficult for a person to manage time in his personal life.

2. PLIW (Personal Life Interference with Work), which refers to the extent to which an individual's personal life interferes with his work life. For example, if an individual has problems in his personal life, this can interfere with the individual's performance at work.

3. PLEW (Personal Life Enhancement of Work), which refers to the extent to which a person's personal life can improve individual performance in the world of work. For 
example, if the individual feels happy because his personal life is pleasant, this can make the individual's mood at work pleasant.

4. WEPL (Work Enhancement of Personal Life), which refers to the extent to which work can improve the quality of an individual's personal life. For example, the skills that individuals acquire at work allow individuals to utilize these skills in everyday life.

\subsection{Role of Religiusity in Work-Life Balance}

God is the purpose of human life. And to achieve that goal, humans need to know who their God is (Fauzan, 2015). Every cell in the human body bears witness to his life so that he can witness the oneness of God, which has all happened since ancient times. This testimony is not only at the oral level, but also in the forms of ritual worship (Fauzan, 2017). In the development of life, humans always seek peace by getting closer to God Almighty, this is supported by the opinion of Hill and Smith (2002) who found evidence that during the decades between 1994 and 2004, the percentage of employees who began to feel that they needed experience religion in their work is increasing, from $30 \%$ to $78 \%$, because this change has made many organizations try to increase the study of religiosity. Several studies have looked at the relationship between religious beliefs such as job performance (Pfeffer, J. 2002), Organizational-based self- 1996. Saputro's research (2006) states that religiosity greatly influences voluntary behavior (Altruism).

These results indicate that religious individuals will always try to do good deeds voluntarily, such as helping others or loving others. This is also consistent with Benson's research (in Allen \& Myers, 1996) which found that individuals who have high religious commitment will spend time working voluntarily. Willingness to work voluntarily is a positive behavior that will lead to good behavior among members of the organization. Willingness to do voluntary work shows that people are willing to do things that are not their responsibility.

This behavior in the world of work will be very beneficial for the company. Because to increase the efficiency and productivity of the organization will depend on the willingness of people in the organization to contribute positively. The behavior to be willing to make positive contributions is expected not only to be limited to formal work obligations, but ideally better than formal obligations. Developing good behavior also requires the creation of a good quality of work life. Employees who have a high quality of work life will encourage the emergence of good behavior, because they are more likely to speak positively about the organization, willingness to help others and do work to exceed what the organization expects. The quality of work life is a level where organizational members are able to satisfy important personal needs through their experience in doing work at the organization (Safrizal, 2004).

According to Cascio (2003), work-life balance is the perception of employees where employees want a sense of security, satisfaction and the opportunity to work and develop like humans. Cascio (2006) added that work-life balance is the employee's perception of work safety, satisfaction, work-life balance and the ability to grow and develop as a human being. Work-life balance according to Cascio (2003) is illustrated in nine components consisting of work involvement, balanced compensation, a sense of security at work, safety of the work environment, pride in institutions, career development, available facilities, problem solving, and communication. Robbins (2001) in Anggreini (2018) states that the factors that influence the perception of work-life components are age, position status, length of office and education. Work-life balance can increase the participation and contribution of members or employees to the organization. According to Spector (in Robbins and Judge, 2008), states that work-life balance is the main determinant of an employee's good behavior. 
In today's organizations, professionals consider meaningful employment, good working or employment conditions, good income, and supportive co-workers as the most influential factors for their professional stability and growth (Mitroff and Denton 1999). Hungelmann (1985) states that the assimilation of work-life balance and employee religiosity predominantly supports transpersonal (relationship with God), interpersonal (relationships with friends and family, etc.), and intrapersonal (relationships with oneself). In this context, work-life balance appropriately includes the extent to which an individual is able to simultaneously balance the temporal, emotional, spiritual and behavioral demands of paid work and family responsibilities (Hill et al, 2001). Therefore, when an individual is detached at work or in personal life if he is able to recognize that their existence, achievements, and well-being in life / work depend on mutual dependence on one's inner self, relationships with close and dear ones and above. Everything that is God, they will probably move towards greater harmony and effectiveness towards their work lives.

The achievement of affiliation in the context of the workplace articulates that, religiosity is an interrelated religious experience between those involved in the work process, initiated by sincerity, reciprocity and personal goodwill evoked by a deep sense of meaning in work in the organization and produces greater motivation and organizational excellence (Marques, Allevato and Holt 2008).

In the organizational perspective the suitability of work-life balance and religiosity emphasizes that the company or organization must provide a place and opportunity for employees to express different aspects of a person at work (Ashmos and Duchon, 2000) and especially the role of the Personnel functionaries is to explore ways a way that allows employees to find meaning in their life and work through the religious activities of the work performed.

The values of religiosity that are applied in personal life and are possible to be adopted as part of the organizational system and family morals, will help individuals understand the complexity of roles and motivate them to interpret life so as to achieve life satisfaction or happiness (well-being). There are several principles that are emphasized in applying the religious values system in Islam (Alhabsyi, 1992), namely:

1. Individual character development, is a psychological area that produces consistent and spontaneous behavior, so that when the spontaneous behavior is consistent with 'animal' behavior, the character will be assessed as 'animal' character which is considered bad only to promote desire, lust, and not. the need to achieve useful goals.

2. Orientation to monotheism, namely affirming Allah and not associating other things, for example defined as the attitudes and ways of a person behaving that do not tend to crime or harm (dzolim) to others.

3. Vicegerency is a description of individual behavior in completing tasks as part of obedience to Allah and as guardians of Allah (khilafah).

4. Justice is behavior that does not impose a duty or responsibility on others, even if people are not liked. These principles will build an Islamic personality who has an attitude of gratitude in everything he gets by maximizing what is available.

This will build meaningful life that will help individuals understand every experience that occurs and are committed to the vision and mission of their life. The application of religious values in the organization to achieve work-life balance can be done for example by creating a positive work environment, including:

1. The importance of prioritizing family life over work. This is in accordance with the message of the Prophet Muhammad that the duty of a family leader is to keep the family away from hellfire. 
2. Being prudent, namely formulating fair and flexible principles so that it is possible when there are urgent conditions in the family, it should be resolved first but not neglect the responsibilities that must be resolved.

3. Understand the job description with clear procedures.

4. Always expand knowledge in order to become an expert in their field or work.

It is hoped that the principles of religious values can be applied by employees to form an organizational culture that provides a significant role in predicting the benefits of a workfamily system (Thompson et al., 1999) as an effort to build work-life balance so that employee perceptions of a supportive work environment are created. (Allen, 2001; Behson, 2002, 2005; Clark, 2001; O'Driscoll et al., 2003).

Achieving work-life balance for employees will result in the attainment of quality of work-life (Greenhaus et al., 2003). The values of religiosity that are developed in employees are not only aimed at achieving quality of work-life but also have an impact on the achievement of organizational effectiveness which is reflected in the vision and mission and strategic plans to achieve organizational goals. Thus, the gap between the achievement of needs, goals of organizational members and company goals can be minimized because of the support of a high religiosity value system.

\section{Conclusion}

Work-life balance is important for the life of someone who has a complex role. Several issues in the achievement of welfare can be explored through health conditions, financial situations, work, leisure, household and environment (van Praag et al., 2003) or satisfaction in life, social life, sexual life, relationships with others, self. alone, physical appearance, family life, school life, and work (Alfonso et al., 1996). Therefore, the purpose of this paper is to describe the importance of fostering a work-life balance in order to achieve meaningfulness in life and a functioning role in a family that is oriented towards achieving a prosperous life in life and work.

However, the role of religiosity that shapes the cultural environment in which individuals interact becomes complex, so it is necessary to apply religious values possessed by Indonesian people, especially employees, namely religious values or religiosity. The approach used in this research is a literature review that requires empirical support through in-depth research results. Through this paper, it is hoped that it can provide benefits to the development of psychology that is oriented towards positivism and religiosity as part of aspects of human life. Hopefully the implementation of religiosity values can be used as material for reflection to build a harmonious life system and provide mutual benefit to all mankind and the universe.

\section{References}

Adhim, F.(2009). Pengaruh Religiusitas Terhadap Prestasi Kerja Pegawai Alumni Dan Bukan Alumni Pesantren (Studi pada Kantor Depag Kabupaten Bangkalan). Jurnal Ekonomi MODERNISASI Fakultas Ekonomi - Universitas Kanjuruhan Malang http://ejournal.ukanjuruhan.ac.id

Alfonso, V.C. Measures of quality of life, subjective well-being, and satisfaction with life. In D.B. Allison (Ed.), Handbook assessment for eating behaviors and weight-related problems. Thousand Oaks, CA: Sage, 1995, pp. 23-80

Alhabshi ,S. O. (1992). Universal Applicability of Islamic Values. http://vlib.unitarklj1.edu.my/staff- publications/datuk/ISVALUES.pdf 
Allen, T.D. (2001). Family-supportive work environments: The role of organizational perceptions. Journal of Vocational Behavior, 58, 414-35

Allen, N. J. \& Meyer, J. P. (1996). Affective, continuance, and normative commitment to the organization. Journal of Vocational Behavior, 49, 252- 276.

Ancok, Djamaluddin dan Suroso. 2001. Psikologi Islami. Yogyakarta: Pustaka Pelajar.

Anggraeni, P. N. (2018). Hubungan Jenjang Karir dengan Work-Life Balance Pada Wanita Karir. UIN Sunan Ampel Surabaya: Skripsi

Arwani, A. 2013. Peran Spiritualitas dan Religiusitas bagi Guru dalam Lembaga Pendidikan. Forum Tarbiyah Vol. 11, No. 1, Juni 2013

Ashmos, D.P. \& Duchon, D. (2000). Spirituality at work: A conceptualization and measure, Journal of Management Inquiry; Thousand Oaks, 9(2), 134-145

Behson, S.J. (2002). Which dominates? The relative importance of work-family organizational support and general organizational context on employee outcomes. Journal of Vocational Behavior, 61, 53-71.

Behson, S.J. (2005). The relative contribution of formal and informal organizational work-family support. Journal of Vocational Behavior, 66, 487-500.

Cascio, Wayne F. (2003). Managing Human Resources: Productivity, Quality of Work Life, Profits. New York: Mcgraw and Hill.

Cascio, W.F. (2006). Managing Human Resources : Productivity, Quality of Life, Profits. McGraw-Hill Irwin.

Chusmir, L.H.. Kobem C.S. (1988). Religion and attitudes toward work: a new look at an old question. Journal of Organizational 13(470140r. $9: 251-262$.

Clark,S.C. 2001. Work Cultures and Work/Family Balance. Journal of Vocational Behavior, $58,348-365$.

Elci Meral. (2007). ElTect of manifest Needss. religiosity and selected demografics on hard working: an empirical inN estintion in Turkey. Journal of International Business Research. 6 (2).

Fauzan, A. (2015). Allah, Huwa, Anta dan Ana (Mengenal Allah Melalui Tradisi Tasawuf). Al-Hikmah Vol 9, No 1 (2015)DOI : 10.24260/al-hikmah.v9i1.88

Fauzan. (2017). Membaca Fenomena Shalat Sebagai Sebuah Tanda (Telaah Kritis DialektikaNormatif dan Semiotik Tentang Shalat Wajib). Jurnal Dakwah dan Komunikasi STAIN Curup-Bengkulu | E-ISSN: 2548-3366 ; P-ISSN: 2548-3293

Fauzan \& Tyasari, I. (2012). Pengaruh Religiusitas Dan Etika Kerja Islami Terhadap Motivasi Kerja. Modernisasi. Volume 8, Nomor 3, Oktober 2012

Fisher, G., Bulger, C., \& Smith, C. (2009). Beyond Work and Family: A Measure of Work/Nonwork Interference and Enhancement. Journal of Occupational Health Psychology. 14(4), 441-456.

Ford. R.. Richardson. W. (1994). Ethical decision making: a review of empirical literature. Journal (yr Business Ethics. 13 : 205-221.

Frone, M.R., (2000). Work-family Conflict and employee psychiatric disorder: The national comorbidity survey. Journal of Applied Psychology, Vol.85 No.6,.

Greenhaus, J.H., Collins, K.M. \& Shaw, J.D. (2003). The relation between work-family balance and quality of life. Journal of Vocational Behavior, 63, 510-31.

Greenhaus, J.H. dan Powell,G.N. (2006). When work and family are allies: A theory of work-family enrichment. Academy of Management Review, 31, 72-92.

Greenhaus, J.H., Collins, K.M., and Shaw, J.D. (2003), 'The relation between work family balance and quality of life,' Journal of Vocational Behavior, 63, 3, 510-531.

Guest, D. E. (2002), 'Perspectives on the study of work-life balance,' Social Science Information, 41, 2, 255-279. 
Hasibuan, Malayu S.P. (2009). Manajemen Dasar, Pengertian, Dan Masalah. Jakarta: PT Bumi Aksara.

Hawari, D. (1996). Al-Qur'an: Ilmu Kedokteran Jiwa dan Kesehatan Jiwa. Jakarta: Dana Bhakti Prima Yasa.

Higgins, Christopher A., and Duxbury, Linda E. (2010). "Work-Family Conflict: A Comparison of DualCareer and Traditional-Career Men". Journal of Organizational Behavior, 13: 389-411.

Hill EJ, Hawkins AJ, Ferris M, Weitzman M: Finding an extra day a week (2001): The positive influence of perceived job flexibility on work and family life balance. Firm Relations.

Hill, P. C. and G. S. Smith. (2002). "Coming to terms spirituality and religion in the workplace.” In Giacalone, R. A. \& Jurkiewicz, C. L (Eds.) Handbook of Workplace Spirituality and Organizational Performance, M. E. Sharpe, New York, NY, 2002.

Hungelmann, J. (1985). Spiritual well-being in older adults: Harmonious interconnectedness, Journal of Religion and Health, 24(2), 147-153

Kibuuka. (2005). Religiousity and Attitudes on Intimacy, Thesis. Duquesne University. diunduh 4- 09-2009. http://etd1. library. duq.edu/kibuuka-thesis.pdf, hal. 76-79

Mangunwijaya, Y.B. (1982). Sastra Dan Religiositas. Jakarta: Sinar Harapan.

Marques, Joan F., Eugene Allevato, and Svetiana Holt. (2008) Linking quality management and emotional intelligence to workplace spirituality. Organization Development Journal, 26(4), 81-88

McClelland, D.C. (1961). The Achieving Society. Princeton,NJ: Van Nostrad.

Mitroff, I. I., and Denton, E. A.: (1999a), A study of spirituality in the workplace. Sloan Management Review, Vol. 40; p. 83-92.

Mitroff, I. I., \& Denton, E. A. (1999b). A spiritual audit of corporate America. San Francisco: Jossey-Bass Inc.

Muhaimin. (2015). Paradigma Pendidikan Islam. Bandung: PT Remaja Rosdakarya. hlm. 293-297

Najiyah, F. (2017). Pengaruh Nilai-Nilai Religiusitas Terhadap Loyalitas Kerja Agency Pada PT. Takaful Umum Cabang Surabaya. OECONOMICUS Journal Of Economics

Nashori dan Mucharam. (2002). Mengembangkan Kreativitas: Perspektif Psikologi Islami, Yogyakarta: Menara Kudus, hal. 72.

Nawawi. (2011). Manajemen Sumber Daya Manusia: Untuk Bisnis Yang Kompetitif, Gajahmada University Press, Yogyakarta

O’Driscoll, M.P., Poelmans, S., Spector, P.E., Kalliath, T., Allen, T.D., Cooper, C.L. \& Sanchez, J. (2003). Family-responsive interventions, perceived organizational and supervisor support, work- family conflict and psychological strain. International Journal of Stress Management, 10, 326-44.

Pfeffer J. (2003), 'Business and the Spirit: Management Practice that Sustain 'Values', in Giacalone R. A. and Jurkiewicz C. L. (eds.). Handbook of Workplace Spirituality and Organizational Performance, M.E. Sharpe. New York

Prasetyo, E. (2017). Pengaruh Penerapan Etika Kerja Islam Dan Tingkat Religiusitas Terhadap Kinerja Karyawan Perbankan Syariah Dengan Pendidikan Sebagai Variabel Moderasi. Fakultas Ekonomi Bisnis Islam Institut Agama Islam Negeri Salatiga.

Ramadhani, M. (2013). Analisis pengaruh keseimbangan kehidupan kerja terhadap kesuksesan karir (studi pada karyawan PT. Asuransi jiwa gerenali Indonesia). Jurnal FEB Universitas brawijaya malang.

Robbins, P. Stephen. (2008). Organizational Behaviour, Tenth Edition (Perilaku Organisasi Ke Sepuluh), alih bahasa Drs. Benyamin Molan. Salemba Empat: Jakarta. 
Rakhmawati, I. (2017). Implementasi Karakter Religius Pada Karyawan Pt. Royal Korindah Purbalingga Tahun 2017. Jurusan Pendidikan Agama Islam Fakultas Tarbiyah Dan Ilmu Keguruan Institut Agama Islam Negeri Purwokero

Robbins, Stephen P. (2001). Perilaku Organisasi: Konsep, Kontroversi, Aplikasi, Jilid 1, Edisi 8, Prenhallindo, Jakarta.

Robbins, S. P. \& Judge. (2008). Perilaku Organisasi Buku 2. Jakarta : Salemba 4 hlm. 256

Safrizal, H.A., (2004). Analisis Faktor-Faktor Kualitas Kehidupan Kerja yang Ber pengaruh Terhadap Komitmen Organ- isasi Karyawan PT Petrokimia Gresik. Skripsi. UNAIR Surabaya.

Saputro, Denny. (2006). Hubungan Antara Tingkat Religiusitas Dengan Tingkah Laku AltruisPada Mahasiswa Yang Beragama Islam, Skripsi (tidak di publikasikan)

Schermerhorn, J. R., Hunt, J. G., \& Osborn, R. N. (2005). Organization Behavior: 9th Edition. Amerika Serikat: John Wiley \& Sons, Inc.

Simmons, ES. (2005). Religiosity and work related attitudes among non profesional and profesional staff in assisted living. Journal of Religion, Spirituality and Aging. 18 (I) : 65-82.

Singh, J. (2013). Individual and Organizational Strategies to Balance Work-life with Indian Way. Global Journal of Management and Business Studies. ISSN 2248-9878 Volume 3, Number 3 (2013), pp. 203-210

Siregar, F.H. (2020). Relationship Emotional Intelligence with Conflict Management in Employees of PT. Aspacindo Kedaton Motor. Budapest International Research and Critics Institute-Journal (BIRCI-Journal). P. 1251-1261

Thompson, C.A., Beauvais, L.L. \& Lyness, K.S. (1999). When work-family benefits are not enough: The influence of work-family culture on benefit utilization, organizational attachment, and work-family conflict. Journal of Vocational Behavior, 1999, 54, 392415.

Ula, I. I , Widyasari, S. D., \& Susilawati, I. R. (2015).Hubungan Antara Career Capital Dan Worklife Balance Pada Karyawan Di PT. Petrokimia Gresik.Jurnal Psikoislamika. Malang: Fakultas Ilmu Sosial dan Ilmu Politik, Universitas Brawijaya. Vol. 12, No. 1, Halaman: 13-22

Van Praag, B.M.S., Frijters, P. \& Ferrer-i-Carbonell, A. (2003). The anatomy of subjective wellbeing. Journal of Economic Behavior and Organization, 2003, 51, 29-49

Weaver, G.R., Agle, B.R. (2002). Religiosity and ethical behavior in organizations: a symbolic interactionist perspective. Academy of Management Review. 27: 77 -97.

Yusuf, S \& Khan, S. (2015). Work Life Balance in Relation to Well-Being of Religious and Non-Religious Employees. The International Journal of Indian Psychology ISSN 23485396 (e) | ISSN: 2349-3429 (p) Volume 2, Issue 3, Paper ID: B00350V2I32015

Zuhairini et al. (1993). Metodologi Pendidikan Agama, (Solo: Ramdhani, 1993), hlm. 22. 